\title{
Communities Decentralized in Front of Urban Disorders in Abidjan. The Case of Riviera-Bonoumin in the Municipality of Cocody (Côte d'Ivoire)
}

\author{
Abodou Athanase Adomon1,2, Emilienne Angeline épse Koffi Beba ${ }^{1,2}$, Teré Gogbe² \\ ${ }^{1}$ Institute of Tropical Geography (IGT) of the University Félix Houphouët Boigny, Abidjan, Côte d'Ivoire \\ ${ }^{2}$ Group of Research Espace-Système and Prospective (LARESP), Abidjan, Côte d'Ivoire \\ Email: athanaseadomon@yahoo.fr
}

How to cite this paper: Adomon, A. A., Beba, E. A. K., \& Gogbe, T. (2018). Communities Decentralized in Front of Urban Disorders in Abidjan. The Case of Riviera-Bonoumin in the Municipality of Cocody (Côte d'Ivoire). Current Urban Studies, 6, 121-137.

https://doi.org/10.4236/cus.2018.61006

Received: December 9, 2017

Accepted: March 13, 2018

Published: March 16, 2018

Copyright $\odot 2018$ by authors and Scientific Research Publishing Inc. This work is licensed under the Creative Commons Attribution International License (CC BY 4.0).

http://creativecommons.org/licenses/by/4.0/

\begin{abstract}
Situated in the "chic" municipality of Cocody, Riviera-Bonoumin as all the districts of the District of Abidjan, does not escape the phenomenon of the urban disorder. Faced with this unsightly landscape-level of modern times, operations of forced displacement of spaces illegally busy, works of drainage and healthiness, unexpected police visits on public domains illegally busy and in a anarchy way, take-off of posters and wild advertising hoardings, etc. are actions carried out by the municipality with the support of The Ministry of the Urban Healthiness. These actions can be effective, if the citizens are associated as mechanism of follow-up and control in the process.
\end{abstract}

\section{Keywords}

Urban Disorders, Cocody, Municipality, Anarchic Occupation, Riviera-Bonoumin

\section{Introduction}

A hasty observation of the urban landscapes and their use in Africa reports that "the tropical urban spaces of Africa in the South of Sahara know spatial and demographic changes" (Soumahoro \& Étongué, 2014: p. 37). This metamorphosis is made by a mixture of finished and of unfinished; consequence of the complementary necessities undertaken by the effort of participation in the modernity of the populations. Yet, the closeness of the precarious housing environment with the residential housing environment which is a factor of these change, is reveal- 
ing major challenges in the management of the urban spaces (Attahi, 2001). In Côte d'Ivoire as everywhere in sub-Saharan Africa, this disorder noticed in the urban spaces testifies of a social dysfunction connected to a lack of urban quality and legibility of the urban space (extracted from the speech of The Ministry of the Urban Healthiness, 2012: p. 8).

Embryonic in 1960, the urbanization in Côte d'Ivoire indeed knows, an accelerated growth rate today. From $17.68 \%$ in 1960 to $36.83 \%$ in 1980 , he passed from $43.53 \%$ in 2000 to $53.48 \%$ in 2014 according to the RGPH-2014. With an urban population estimated at more than 11,370,347 inhabitants in 2014 among which $38.7 \%$ in the District of Abidjan, the Ivorian political capital is confronted with a phenomenon of landscape degradation, characteristic of an urban disorder (Bouquet \& Kassi, 2014: p. 6).

Formerly model of elitist urban development in the 1980 years, the municipality of Cocody does not escape this landscaped degradation. The urban disorder is more perceptible in Riviera-Bonoumin, a zone of extension, situated in the North of Riviera 2, and built on a surface about $4 \mathrm{~km}^{2}$. "The site of Bonoumin is in the continuation of a pond of thunderstorm where waters of flow rise until a height which can reach $200 \mathrm{~m}$ approximately during the rainy season" (Kamenan, 2007: p. 57). What exposes it to frequent floods? On the topographic plan, Bonoumin is in the confluence of two of talwegs in the shape of "Y" knocked down, bounded by three crests. These crests situated in the Bonoumin East and the Bonoumin West, reach a height of $56 \mathrm{~m}$. Slopes are there strong (more than 10\%); while slopes are worthless in the southern part, in particular around the Boulevard Mitterrand (Ministry of the Environment, the Construction and the Town Planning, 1993), where from the risk of a possible sliding of ground. It is this geographical space, limited to the South by the district Boulevard François Mitterrand, on the West by that of Both Trays, in the East by Riviera-Palmeraie and in the North by Cocody extension (Figure 1), and occupied, today, to $90 \%$ by the residential housing environment and to $10 \%$ by the precarious housing environment which is our field of investigation.

In this geographical space, the landscape degrades gradually and the disorder settles down everywhere. The precarious housing environments are built in slums, along the way of connection of Bonoumin East-West, in talwegs, on the sides of hill and on the not emphasized prizes. As "the disorder and the anarchy in cities do not allow to satisfy the human basic needs" (Vasseur, 1997: p. 163). It is a question through this contribution of arresting how the municipal authorities react in front of urban disorders which expose the populations of Riviera-Bonoumin to diverse nuisances in the municipality Cocody?

The present contribution aims at estimating the impact of the urban disorder in the dynamics of the urban development and on the frame the life at Riviera-Bonoumin. She articulates around forms of urban disorders in her Riviera-Bonoumin and their impact on the dynamics of the municipal development first, and second, on the actions undertaken by the municipality to slow down 


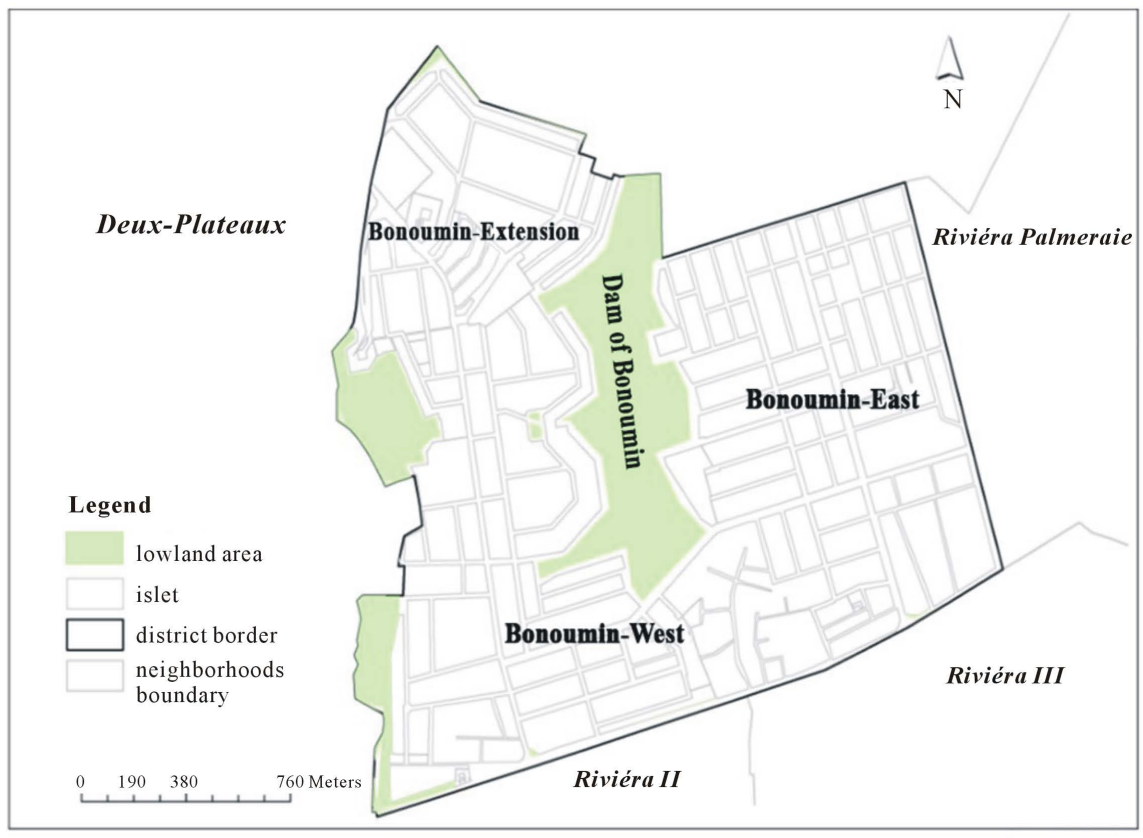

Source: CCT/BNETD. 2006

Dessin: BEBA Angeline E

Figure 1. Geographical demarcation of Riviera-Bonoumin in the municipality of Cocody.

this phenomenon of disorder and some recommendations for a healthy living environment.

\section{Method}

The methodological approach leans on the exploitation of the documentation relating to the activity of the urban space, to the environmental profile, to the regulations regarding land management and to the urban dynamics in Côte d'Ivoire and somewhere else. Then, an observation was realized on the ground in 2014 then completed in 2017. This observation allowed to identify the forms of urban disorder, to appreciate the state of the environment and the evolution of the urban space and especially the actions undertaken by the municipal authorities in Riviera-Bonoumin. An interview was also realized with people resources implied in the urban politics of the municipality and the waste management (the technical department head, the Ministry of the Environment, the Urban Healthiness and the Sustainable development, the Ministry of the Construction, the Housing, the Purification and the Town planning, the National Agency of the Urban Healthiness, the persons in charge of the various service providers of service in the field of the pre-collection, the collection, the transport and the dumping of household waste, the persons in charge of health centers and hospitals to obtain information relative to the environmental diseases, etc.). This interview allowed to collect complementary data on the management of the public domain, the legislation on the subject, on the strategy of collection of the garbage and the management of the living environment, etc. Finally, an investigation guided by questionnaires is realized in 2017 with 100 heads of the house- 
hold over the 2197 identified with Riviera-Bonoumin according to the RGPH-2014 (Inventory Dress rehearsal of the Population and the Housing environment). We proceeded by a choice reasoned according to the following criteria: the age (30 years minimum), the sex (50 men and 50 women), the level of education (34 intellectuals, 32 illiterates and 34 removed from school), the business sector ( 52 people in the formal and 48 people in the informal) and the nationality (48 foreigners and 52 inhabitants of the Côte d'Ivoire). This guided investigation allowed to collect the opinion of the population on its contribution, its needs or its desires in front of urban disorder, and to arrest the consequences of the urban disorder on their living environment. The results are presented.

\section{Results}

\subsection{The Urban Disorder: A Phenomenon Multiform and Degrading of Living Environment with the Riviera-Bonoumin}

\subsubsection{The Public Spaces Illegally Occupied by Informal Activities}

In Riviera-Bonoumin public places and public highways are converted in places where practices the small shop. Of the boulevard Mitterrand in the street André Malraux, including the street crossroads commissionership-city is urgent in that of the street park of Bonoumin-Abri 2000; everywhere commercial activities occupy illegally spaces in the morning and evening and along ways. It is about setting-up of phone boxes, sale of mobile and secondary phones, joiner's workshop, shed of shoe repair store, setting-up of vulcanization, mechanical garage, aprons of sale of doughnuts, fruits, vegetables, of alloco, fried attiéké-fishes, of chickens and braised sheeps (...). We also note the presence of the cabarets where wind the called adulterated liqueur "koutoukou" in the local language. At nightfall, they are delinquents, of prostitutes and drunkards who occupy these spaces. This shape of disorder is at the origin of the new names of money districts underestimated by the municipal authorities. In Riviera-Bonoumin, informal activities settle down on public places of the residential area besides ways and their immediate environments. The investigation allowed to identify what follows (Table 1).

Table 1. Overview of the informal activities. Source: our inquiries 2014, completed in 2017. Design and realization: Adomon and Beba.

\begin{tabular}{ccc}
\hline Types of activities & Staff & Nature of the displays \\
\hline $\begin{array}{c}\text { Current sale of consumer goods } \\
\text { Clothing and secondary articles }\end{array}$ & 50 & $\begin{array}{c}\text { Shed, Parasol, Banks bench, display the } \\
\text { ground }\end{array}$ \\
$\begin{array}{c}\text { Workshops of mechanics and repair of } \\
\text { household electrical appliances }\end{array}$ & 20 & $\begin{array}{c}\text { Container, Store hard, Shed or piece of } \\
\text { waste ground }\end{array}$ \\
Municipal transport & 03 & Shed, Store hard \\
\hline
\end{tabular}


Certain activities such as scrublands, restaurants, refreshment rooms know a proliferation in these spaces about residential houses. The activities of sales of products clothing and the accessories (secondhand clothes shop, hairdressing salons, workrooms) occupy the $3 / 4$ of the 72 stores and displays identified in the sectors of Bonoumin-palmeraie grove, the crossroads police station and the level of the health center at community base of the Riviera-palmeraie grove. The activities of the glaziery, the vulcanization, the hardware store, the washes automobiles are scattered on the territory of Riviera-Bonoumin. We denote besides, three bus stations were illegally implanted on public sites. It is about the station of Bonoumin not far from the big crossroads of Riviera 2; that of Riviera-Palmeraie was situated in the limit Bonoumin-Palmeraie and finally the station of Riviera-Attoban relocalisée today on a public place. The station of the Palmeraie grove installed in border of the boulevard Latrille causes frequent traffic accidents.

Generally speaking, they take place activities of sale of clothes, shoes and leather store around pavements near these stations as the Photograph 1 shows it.

\subsubsection{Many Not Built Spaces, Occupied by the Precarious Housing Environment}

Today, the space of Bonoumin remains still strewed with many not emphasized and not maintained grounds. Indeed these not constructed private spaces are situated near the housing of high status. These spaces shelter precarious housing environments and become for some of the places of wild deposits or places defecation (Photograph 2(a) and Photograph 2(b)).

These housing environments (Photograph 2(a) and Photograph 2(b)) are built with salvaged materials (Boards, some plastic and old sheet steels). The

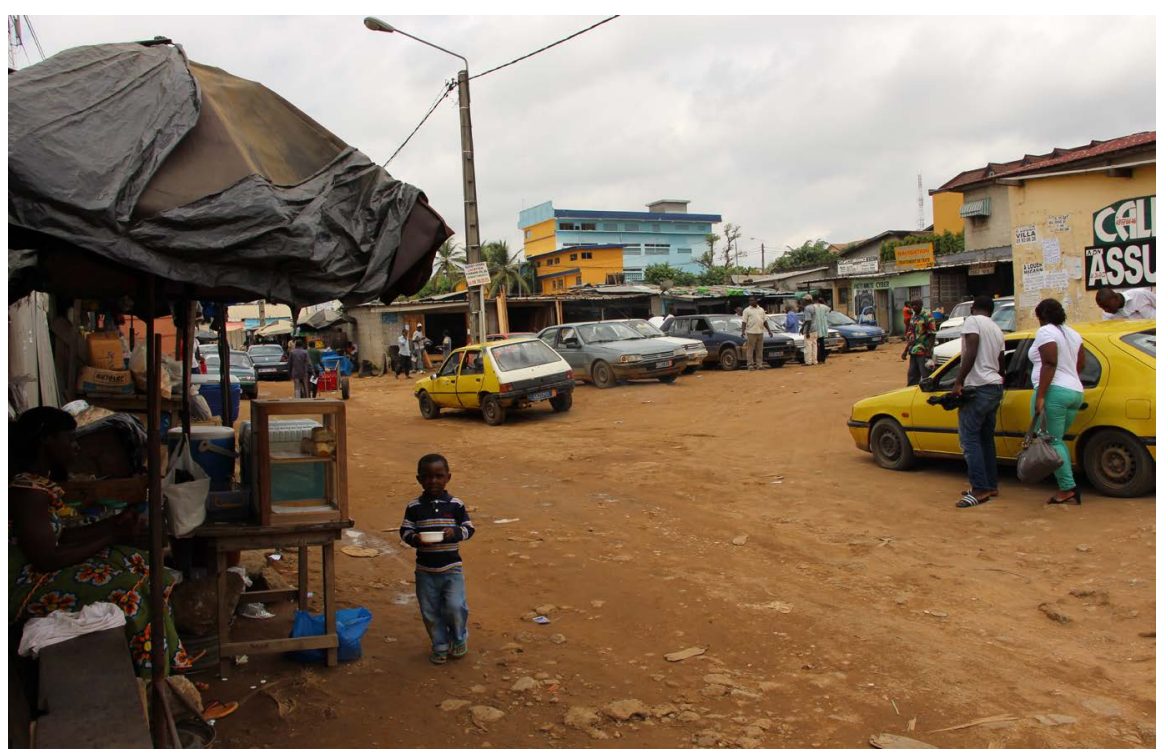

Photograph 1. Watch the entrance of the station of "wôrô-wôrô" of Bonoumin. A cohabitation with the small business of detail. Source: Dumped, 2014. Beba. 


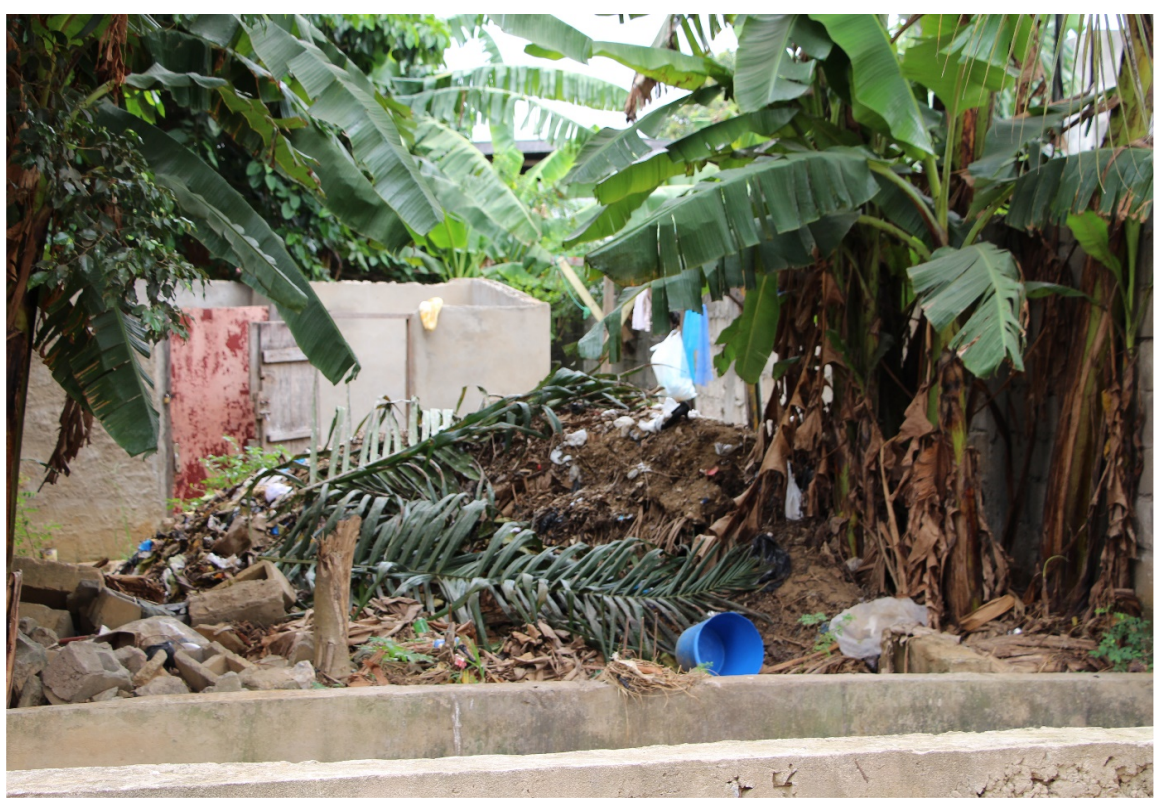

(a)

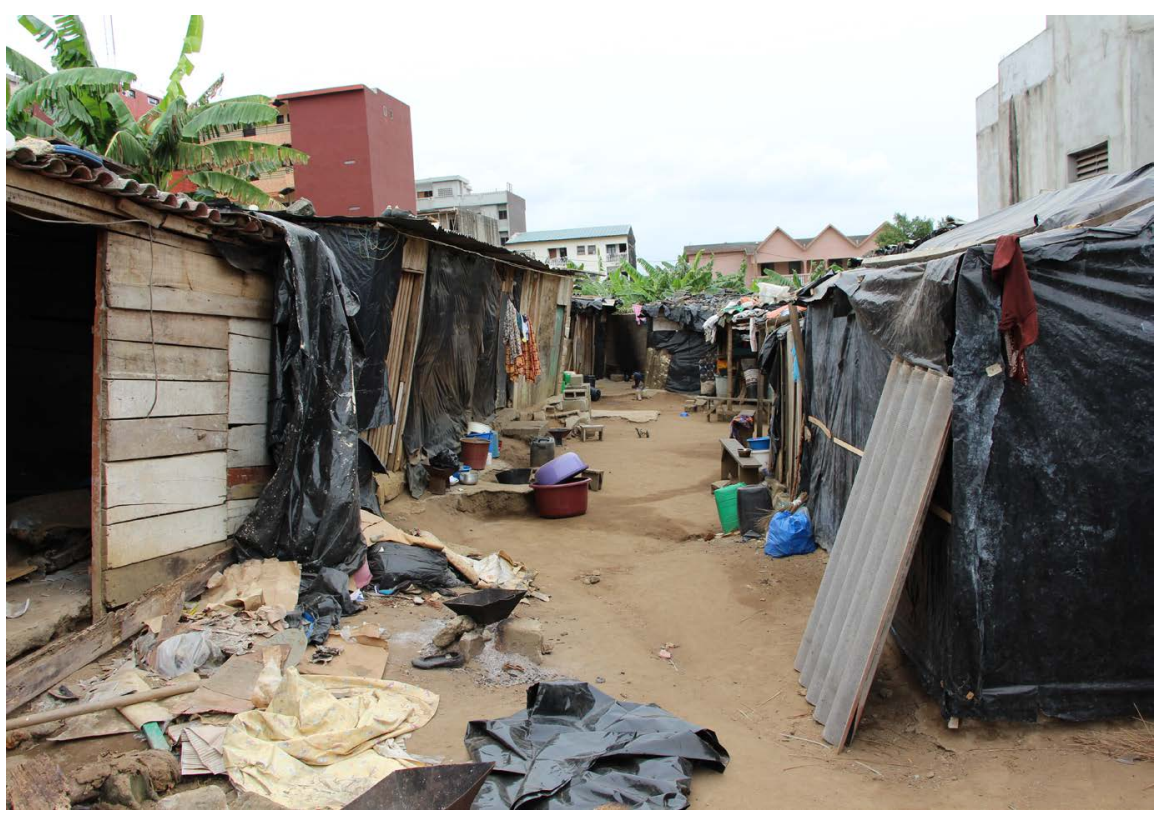

(b)

Photograph 2. Not built Spaces and precarious housing environments to Bonoumin-extension. These images show not built spaces transformed into home of housing environments precarious and in garbage dump under banana trees on the other hand. Source: Dumped, 2017. Beba.

presence of wild deposit of garbage nearby gives evidence of the absence of conveniences.

\subsubsection{Unfinished Constructions and Property Developments in Full Change}

As everywhere in Abidjan, the urban landscape is also degraded by the presence 
of unfinished houses in Riviera-Bonoumin (Photograph 3).

These unfinished houses proliferate in Riviera-Bonoumin for diverse reasons (financial difficulties, deaths, problems of family, land disputes, etc.). These houses are often confided to guards who sublet them to a cost which varies between 10,000 and 20,000 F Cfa according to the geographical situation. These houses which do not arrange a tap water and of electricity, shelter large families living in the precariousness. Sometimes, for needs for conveniences, tenants undertake hastily works of installation of toilets, deceitful connectings of water and electricity.

Except these unfinished houses, houses stemming from property deals undergo modifications, in particular those situated in border of the main ways. These houses are transformed into scrubland, into bars or into restaurants, etc. by their owners. What distorts architectural initial of the construction plan such as to throw by the property developers. Near these scrublands, bars and others, emerge from markets of fortunes or from informal activities which degrade the living environment. In these new trades, arise from conflicts of cohabitation between dissatisfied residents and managers or still between storekeepers and agents of the municipality in charge of the management of the urban spaces.

\subsubsection{The Proliferation of the Wild Deposits of Garbage Spring of Pollution of the Living Environment}

As in most of the districts of Abidjan, Riviera-Bonoumin escapes the proliferation of wild deposits garbage. Streets, crossroads and gutters are blocked by plastic waste coming from the small shop and from the household waste (Photograph 4).

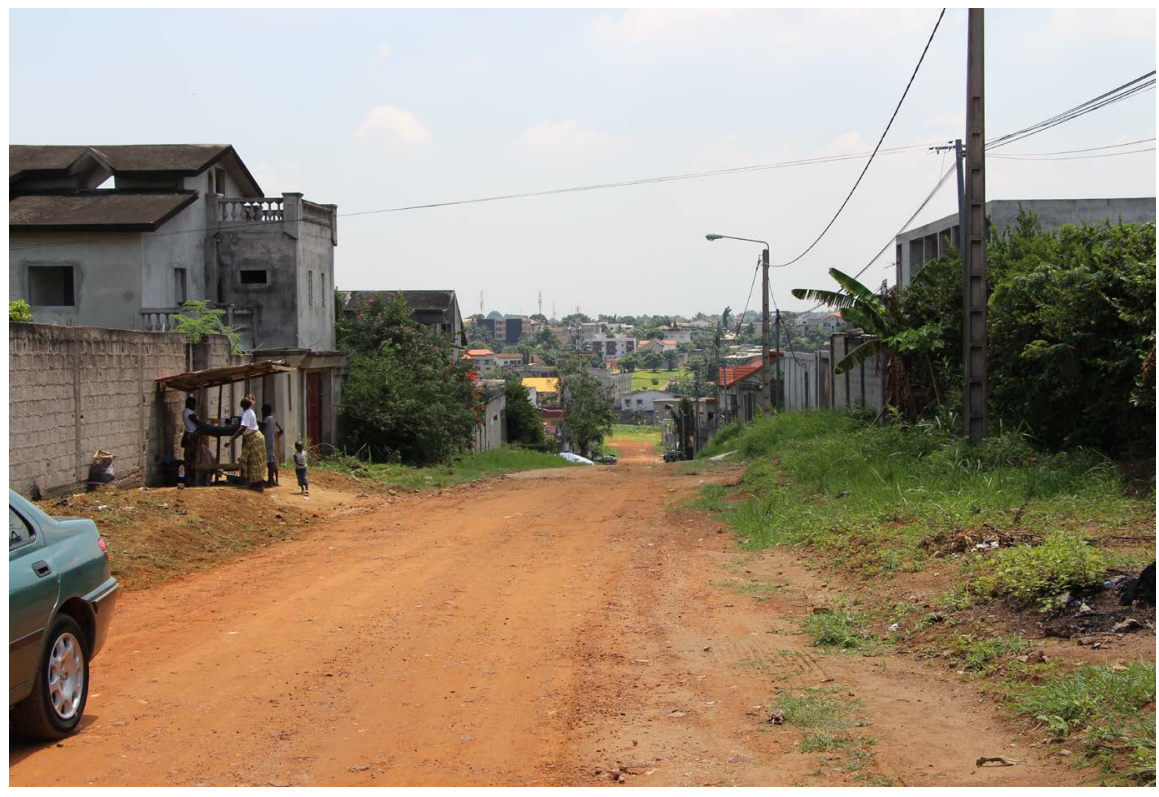

Photograph 3. An unfinished construction the shop window of which is transformed into space of retail trade by the occasional occupants. Source: Dumped, 2017. Beba. 
The irregularity of the trucks of collection of household waste and the insufficiency of safes in garbage are the factors which explain of the presence of the wild deposits of garbage in districts in Abidjan as mentions it to Yopougon (Adomon, 2016: p. 58). This failure in the management system of the garbage is on the base of the pouring on the floor household waste and the obstruction of networks of sewage disposal. In Riviera-Bonoumin, our inquiries revealed that the pollution of the living environment is bound to difficulties of evacuation of waste water and to frequent flood as shown by Figure 2 .

According to neighborhood $28.23 \%$ of the investigated, the created flood more

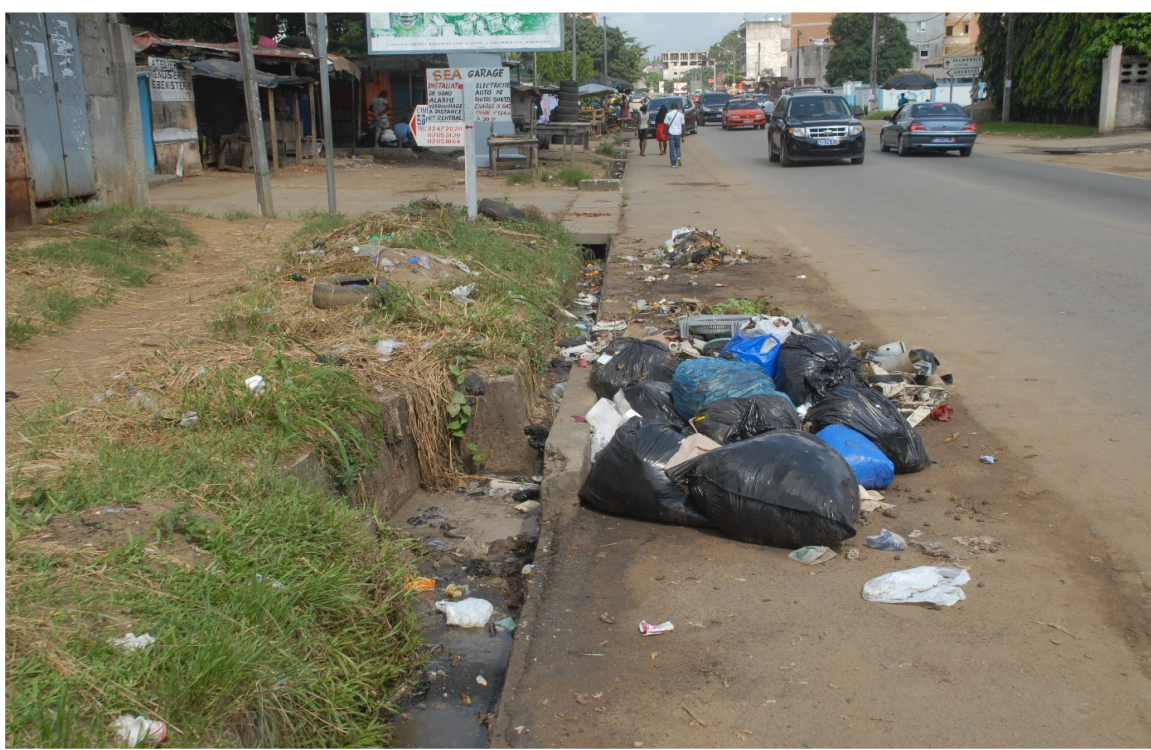

Photograph 4. A gutter blocked, narrow-minded and filled by waste to Bonoumin-Est. In the closeness, the heaps of garbage put down on public roads. Source: Dumped, 2017. Beba.

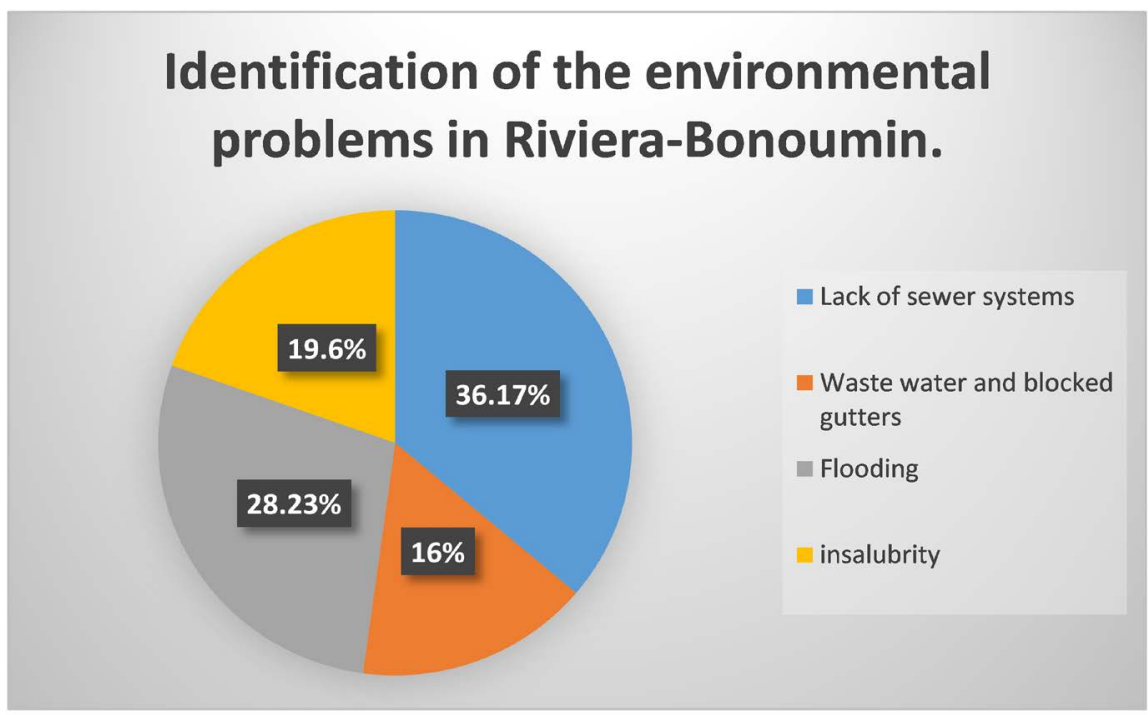

Figure 2. Identification of the environmental problems in Riviera-Bonoumin. Source: Our inquiries 2017. Design and realization: Adomon and Beba. 
damages in Riviera-Bonoumin and causes losses alive human. In 2014, a lady was flooded by rainwater while she cleared himself a passage to join her place work in the sector of Bonoumin village according to the words of the local residents. Udder, the rain provokes dramas and regrettable damage to property as we can notice it on Photograph 5. After the rain, runoff water coming from the Upstream has a very strong current, for lack of pipes, they cause important damages on their passage.

Generally speaking, waste water which stagnate in streets and in open gutters favors the development of the pathogenic agents in Riviera-Bonoumin. In particular, mosquitoes, of insects, flies, sneaks and rodents responsible for numerous diseases: $61.96 \%$ for the malaria; $17.25 \%$ for the respiratory infections; $11.25 \%$ for the diarrhea and the dysentery according to the socio-sanitary data supplied with 2014 by the health center on community base. However, if $16 \%$ of the investigated consider that waste water is at the origin of the diseases; $74.23 \%$ of the investigated question the lack of purification and in the mismanagement of the environment.

\subsubsection{The Uncontrolled Pose of Panels and Advertising Posters in Riviera-Bonoumin}

In Riviera-Bonoumin as in all the districts of Abidjan, the electric and phone poles, the walls, the public buildings, the panels of bus stops, etc. serve as support of advertising posters. What lets appear an arrangement of panels as indicates it the Photograph 6 to the crossroads 9 kilo.

These posters stuck confusedly, degrade the landscaped esthetics of the urban space and are source of insalubrity. When comes a bad weather, these posters are removed by the rain or the wind, leaving ungraceful tracks dirty.

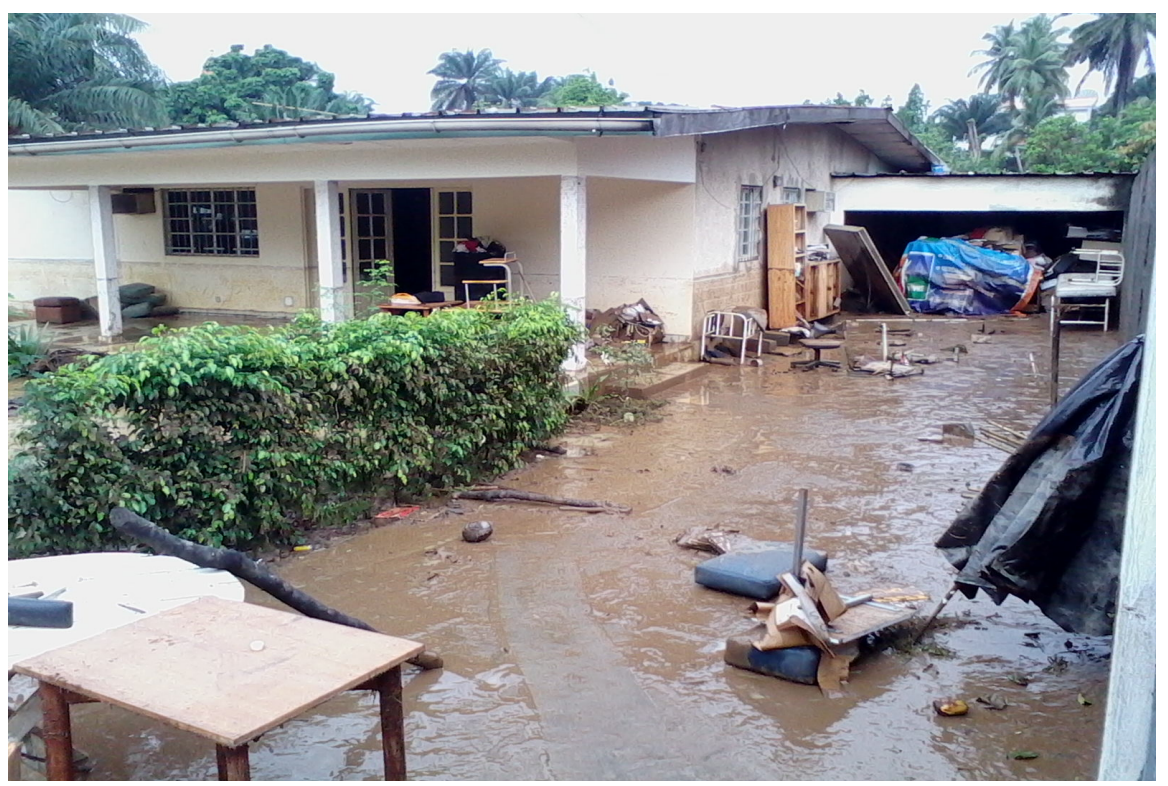

Photograph 5. Flood of a house after a rain in Bonoumin-Est. Source: Dumped, 2017. Beba. 


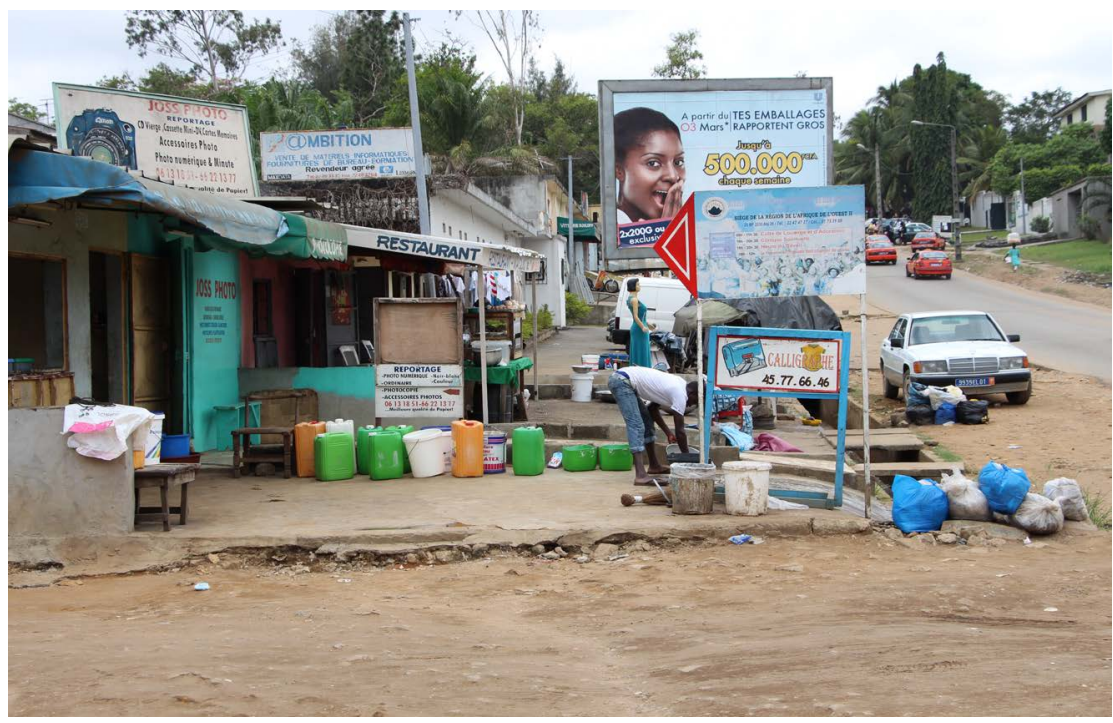

Photograph 6. Anarchy arrangement of posters and panels in the crossroads 9 kilos. Source: Dumped, 2017. Beba.

\subsection{The Reaction of the Municipal Authorities in Front of Urban Disorders to the Riviera-Bonoumin}

\subsubsection{Actions of Control and Police over Public Highways Illegally Busy}

The law n ${ }^{\circ} 2012-1128$ of December 13th, 2012 carrying organization of regions with a measure of autonomy (articles 69,192, 196, and 199), defines the power of control and of police of the municipality over the management of the municipal spaces. In the District of Abidjan, this mission is applied within the limits of its competence regarding management of the domain of the region with a measure of autonomy of its territorial spring. In this connection, the municipality decided to grant a particular attention with care of the coercive rules concerning the anarchy car parks on public road garbage dumps and along the main ways. This practice extends in the geographical space of Riviera-Bonoumin where the municipality delivers licences of car park or temporary deposit on public roads and other public places provided that it does not hamper the traffic or does not hinder the access to the waterside buildings. The offenders expose themselves to verbal penalties or to a payment of infraction according to the offence.

The fines planned for that purpose go of 2.000 in $72.000 \mathrm{~F}$ Cfa with a detention of 10 jours according to the gravity of the breach (article 246 of the decree no. 64-212 of May 26th, 1964) carrying regulations of ways open to the public traffic. Indeed, any illegal car park on the public road network outside parking areas indicated by the municipality is passive of payment of fines.

In a concern of organization, the municipality has created a committee of follow-up to force the motorists to the respect for the rules of car park. Unfortunately, the actions of the aforementioned committee are ineffective in front of the lack of civic virtue of certain motorists.

Concerning the stations of anarchy fortunes, their abolition came up against refusal of the economic operators of the sector. The latter expressed their disap- 
proval through a lasting days work stoppage. The likely option is an appropriate relocation of stations.

\subsubsection{Operations of Forced Displacement of Spaces Illegally Busy and Take-Off of the Temporary Illegal Panels and the Posters}

In Côte d'Ivoire, the activity of the public domain is subjected to a right of user limited by very binding regulations. Any illegal activity is passive of prosecution judicaires. To bring to a successful conclusion this kingly mission, the State creates by the prescription no. 2007-586 of October 4th, 2007, the national Agency of the urban healthiness (ANASUR). This prescription repeals certain statutory provisions no. 2003-208 of July 07th, 2003 carrying transfer and distributions of the skills of the State in regions with a measure of autonomy. The cleaning up of the urban areas initially devolved to communities is confided from now on to the ANASUR. The forced displacement of spaces illegally busy is the process the most used by the ANASUR since the end of the post-election crisis in 2011 to end the occupation of grounds in Côte d'Ivoire. It is a question of forcing to the travel of the city-dwellers installed on a controversial land tax. But it is intended to clean also streets and more generally public places of any commercial activity not planned in the plan of occupation of the public domain (Bouquet \& Kassi, 2014: p. 2). It is as such that the operation of forced displacement of spaces illegally busy called "clean country" took place in 2011 on the whole of the territory after the post-election crisis. But has months of activities, the operation stopped on a taste of unfinished. "The dynamics of the forced displacement of spaces illegally busy gives way to one against dynamics of reoccupation of left public places" (Kouamé, 2015: p. 233); in all the big city centers for lack of follow-up and of control of the committed actions. Consequence, we attend a perpetual resumption of the operations of forced displacement of spaces illegally busy as it is the case in Riviera-Bonoumin (Photograph 7(a) and Photograph 7(b)).

Even if since October 25th, 2017, the ANASUR became the Nationale agency of Waste management (ANAGED), the forced displacement of spaces illegally busy of public places in Abidjan called "Operation Big Household" continues.

Concerning the pose savages of advertising hoardings and posters, an operation of reappropriation of the public place was led by The Ministry of the Urban Healthiness in 2012 in all the municipalities of Abidjan. The operation aimed at unsticking 2000 "illegal" advertising hoardings which did not answer the current and polluting criteria the public place. Just like the operations of forced displacement of spaces illegally busy, the take-off begun in 2012 did not produce the expected result, even if the big brands which took advantage of the anarchy saw revised their policy concerning poster advertising. The failure of this action would be connected to the fact that the complicities with the authorities are very active; where from the all-out expansion of the noticed disorder.

\subsubsection{Works of Cleaning Up and Healthiness Realized But Still Ineffective}

Within the framework of the cleaning up, a dike was realized to receive from the 


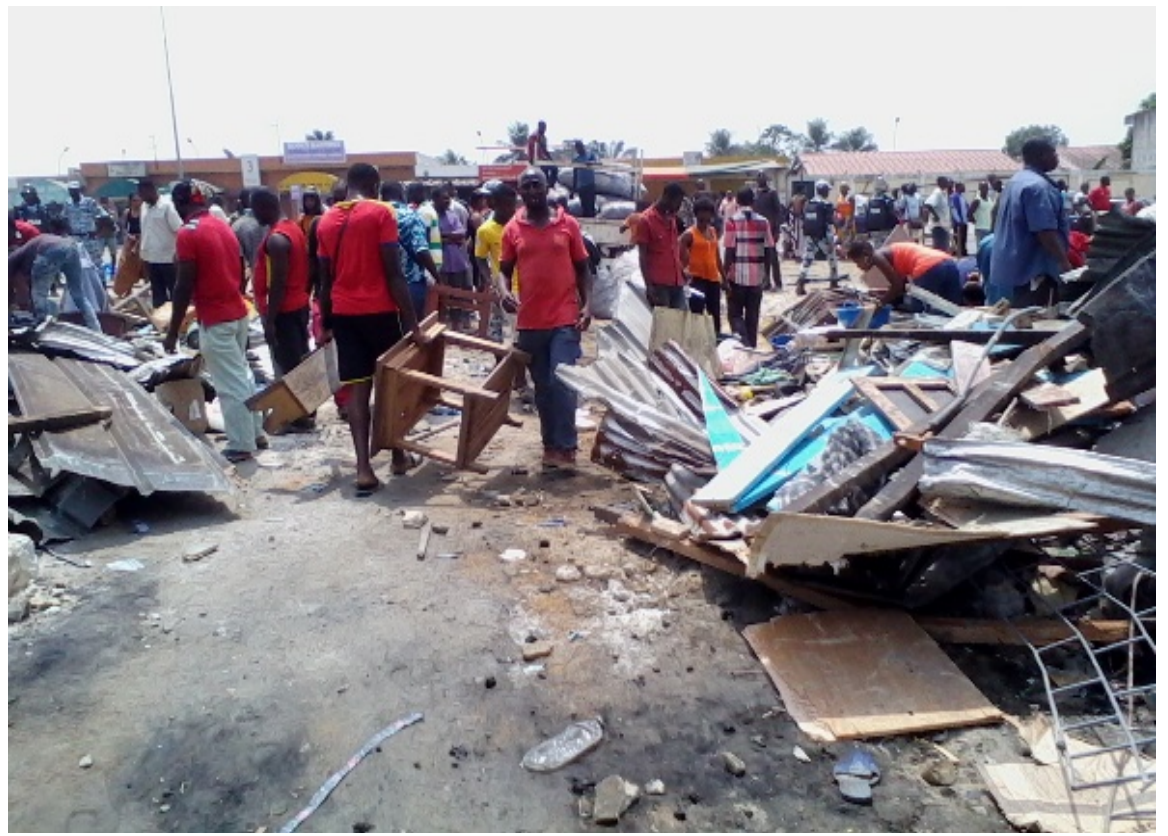

(a)

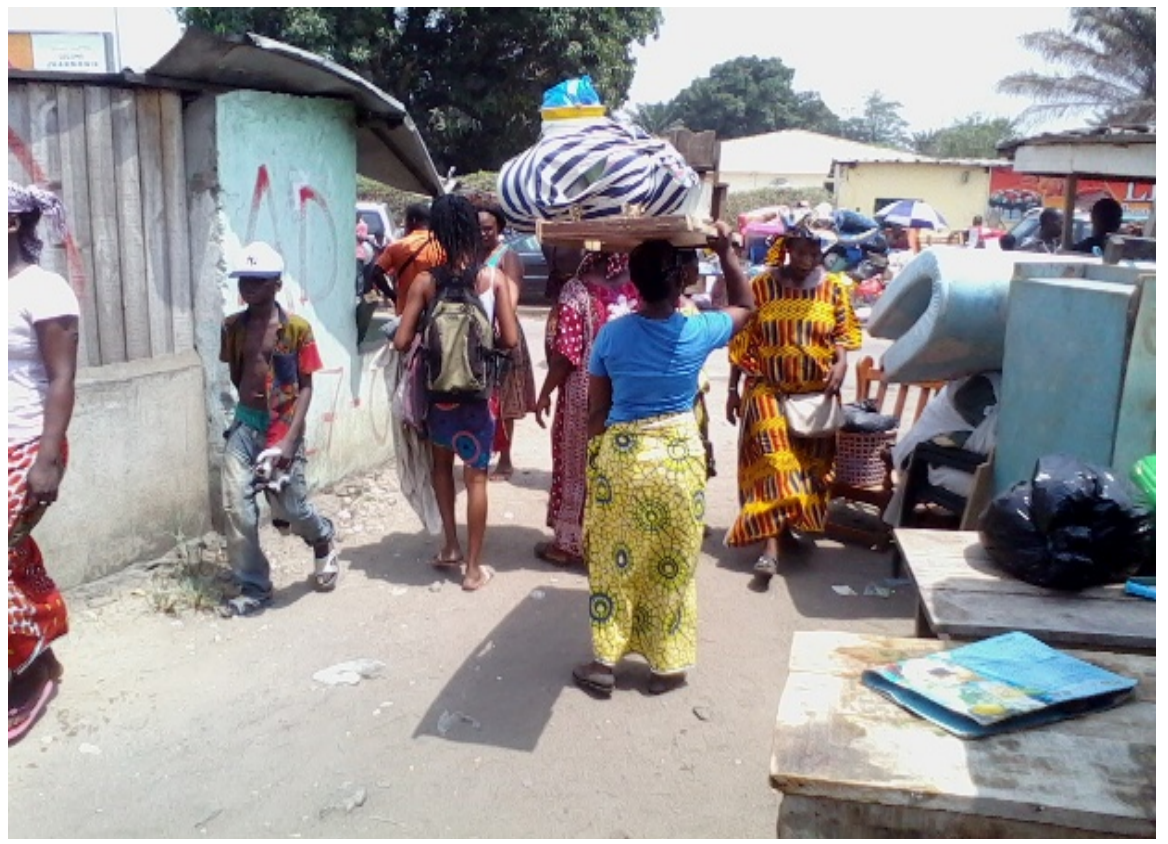

(b)

Photograph 7. Operation of forced displacement of spaces illegally busy near the crossroads. Commissionership and in 9 kilos. Source: Dumped, 2017. Beba.

waste water at the level of Riviera-Bonoumin in 1996 by the municipal authorities (Kamenan, 2007: p. 110). In spite of this work, the floods keep causing damages at the level of the house of the famous artist "ALPHA BLONDY". The water stagnates near the Terminus of buses 28 and 83 because of the obstruction of branch pipes. The completion of the works of the network of drainage planned (Project of cleaning up introduces since about ten year by the Munici- 
pality in the PACOM)) at the level of the traffic circle and towards the health center of the Palmeraie grove is a relief today. However, even if the local residents can be delighted at the effective execution of such a project; damages due to the floods are still legions as it is the case on Photograph 5.

Concerning the healthiness, the City hall tries hard to follow the refuse collection granted to the company 2GIZE. Visits of ground are made by the agents of the service-environment to make sure of the respect for the exercise book of responsibility by the aforementioned company. The management agents of the real estate cities are associated to this control. In case of breach, the latter inform the agents of the City hall. To coordinate this action, weekly meetings take place every Wednesday between the various actors of the process of the pre-collection and the collection of garbage that is the agents of the City hall, the MACOM, 2GIZE, the management agents and the informal private pre-collectors. At the same time, the City hall introduced a training of the private informal pre-collectors to improve the pre-collection as it was the case in 2003 to Yopougon for the precollectors motorized of the City hall (Adomon, 2016: p. 62). Here as to Yopougon, for lack of financing, the project stopped after two sessions of formation. Worse, the sweeping of the main arteries confided (entrusted) to the company "AROMA" runs with difficulty. The company in responsibility would have cash shortage according to the investigated.

As we can notice it, the municipality has the load of coordination of the actions of cleaning up in the municipality. She watches with care of texts and laws and the repression if need. She brings a technical support for the private actors for a better waste management through the informal pre-collectors private as it was the case to Yopougon (Adomon, 2016: p. 62).

\subsubsection{Difficulty of Controllable Speculation in Land by the Municipal Authorities}

According to the land legislation in Côte d'Ivoire, the State is the only owner of the earth. It is him who through the procedures of lot changes the rural ground in urban ground (Atta, 1994). Nevertheless, since 1980 the State grants some privileges to the municipalities which can introduce and realize lots.

However contrary to the municipalities of the inside, in the urban area abidjanaise, the State leads without division the politics of land promotion and its implementation. Municipalities assure only the guarding of the grounds of the State being of its private domain (Diahou, 1990). Thus the municipalities do not have an official and formal authorization to introduce projects of lot. This lack of autonomy affects relations between municipalities and their citizens because "the difficult conjunction of the interests of the city-dwellers and those of the public authorities opens the way for any sorts of practices of land and real estate promotion" (Diahou, 1990: p. 52). As the municipality is responsible as well for the well-being of the population and is defender of the interests of 1'Etat State, she is in a dilemma as if to assuring the déguerpissement of districts built on grounds being of the heritage of the State, especially if they were already the ob- 
ject of a lot.

Indeed, the question of the identification and the clarification of the skills between the City hall, 1'Etat State and the natives landed holders to Cocody settles with acuteness in villages "Ebriés" About the management of urban grounds and land transactions; because certain grounds are still kept by customary authorities (Diahou, 1990: p. 51). Certain natives still consider that the State did not hold its commitment, thus each is free to manage the ground as he understands it. "The sale of grounds becomes a revenue stream for the majority of villages "Ebriés" (Kouadio, 2012: p. 22). This clientelism is practised to the detriment of the rules of town planning as it is the case in Riviera-Bonoumin. In front of such practice, the State has difficulty in applying its interventionist very strict politics of town planning (Dembélé, 1997). He has really no more the monopoly of control of the activity of the urban space to impose a binding exercise book of responsibilities and has difficulty in following the operations of forced displacement of spaces illegally busy. That is why today, the public and private domains are easily managed by uncontrolled and unreliable intermediaries.

\section{Discussion}

\subsection{Ineffectiveness of the Follow-Up and the Control of the Actions of Management of Public Places at the Municipal Level}

The absence of real synergy between the various actors and the absence of strong urban politics to reconquer public places are the main reasons. Indeed, the politics of the "leave-to make" and the ineffectiveness of the operations introduced to there against the insalubrity and the urban disorder failed. It is the case, of the operation "Clean Country" which did not make the unanimity although "it was a question of restoring the order and the urban healthiness and of enforcing the environmental rules and of town planning regulating the activity of the urban space" (Bouquet \& Kassi, 2014: p. 7). The reappropriation of the left spaces wherever from it comes, is synonymic the failure of the mechanism of follow-up and control of the actions undertaken on one hand and on the other hand testifies of the laxness or the unconfessed complicity on behalf of the authorities in charge of this task. These authorities which wish to keep their legitimacy with the voters are guilty actions of reappropriation of the public domain by their dumbness.

However, it is a question by a regulated control, to prevent the informal appropriation of the public place left or cleaned up through a plan to anticipate any forms of contesting against the actions committed by the municipal authorities. The municipality will owe for it, to endow the local police of adequate rolling stocks to facilitate the periodic patrols on the left sites. The left spaces must be fitted out and equipped with collective infrastructures. What would prevent a reinstallation certainly? Awareness campaigns on the regulations of current town planning and the recasement of left on appropriate sites will have to be 
made in a concomitant way. Finally register the strategy of management of the urban space in a participative frame by favoring the know-how of the concerned actors; where the local elected representatives are an initiator of the project and the citizens mechanism of control and follow-up of the committed actions.

\subsection{Effectiveness of the Transfer of Competence in the Municipalities Regarding Land Management in Abidjan}

The analysis of the law no. 85-582 of July 29th, 1985 wearing know-how transmission shows that tasks still have difficulty in being transferred to local authorities in several fields of intervention. "This limited character and of unfinished in the reduced transfer of the skills considerably the field of intervention of the local actors" (Adomon, 2015: p. 278). Indeed, in the field of the spatial arrangement of the municipal territory and the management of the urban land tax, the municipalities of Abidjan are not really involved in decision-making. They content with expressing a simple opinion within the committees of attribution and management of the local land tax. Yet on the ground, neither the Ministry of the construction, the town planning and the housing environment, nor the District of Abidjan even less City halls do not master the control really of their sphere of influence. What gives rise to conflicts of endless jurisdiction. This incomprehension between the actors, favors the illegal and anarchy activity of grounds by the users. The State will have to revise texts establishing the statutory commissions on the land tax by giving to the municipalities of Abidjan, the superiority in the management of the municipal land tax, which supposes the clear implementation of a frame of legal execution and the objectives of protection of the living environment and the environment.

\subsection{Implementation of a Mechanism of Control and Follow-Up of the Actions Municipal as Strategy of Job Creation}

The strategies of fight committed against the urban disorder to Riviera-Bonoumin by the municipality did not produce the result expected to this day. In particular in the strict respect for all the texts in particular legislative, statutory and the procedural rules regarding fight against the urban disorder on one hand and on the other hand in the organization of awareness campaigns, educational and information of the populations. What supposes an effective mechanism of control and follow-up of the actions undertaken through:

1) An application strictly the legislative and statutory texts as well as the procedural rules regarding fight against the urban disorder;

2) One to strengthen the legislative and statutory existing texts to adapt them to the concept of urban disorder;

3) A follow-up of the application of the prescriptions contained in the documents of town planning;

4) The modification of certain statutory provisions no. 200 3-208 of July 07th, 2003 carrying transfers and distribution of skills of the State in the decentralized 
communities and the subsequent decrees regarding town planning and regarding housing environment;

5) The elaboration and the implementation of communication plans under the supervision of the municipal authorities to facilitate the distribution of the messages of healthiness;

6) The creation of the municipal committees of healthiness asked to popularize the legislative and statutory texts;

7) The organization of the competitions of healthiness in the level of sub-districts;

8) To capitalize best practice and to exchange the experiences between the management committees of sub-districts.

In the feasibility, we shall subdivide the territory geography of Riviera-Bonoumin into three sectors: Bonoumin East; Bonoumin-extension and Bonoumin West (Figure 1). Every sector, we shall affect a municipal committee of healthiness, compound of around thirty (30) at least resident people in every sector. The sectorial committee responsible for the control and responsible for the follow-up of the municipal actions in the sector which his will be supported in its mission by interventions of the municipal police. These actions of supervisions will be relieved by the municipal committee of healthiness in every sector. These municipal officers of healthiness allocated only to the task of the follow-up and the control will undergo beforehand a formation relative to the urban healthiness, to the knowledge of texts and legislation regarding urban management. In return, the municipality would interest them monthly, which would give a permanent employment to at least 100 people on the municipal territory of Riviera-Bonoumin to Cocody. Such a project, generalized in all the municipal perimeter of Cocody, would reduce to doubt it the rate of the youth unemployment in the municipality.

\section{Conclusion}

Following the example of other districts of Cocody, Riviera-Bonoumin suffers from an urban disorder realized by the anarchy occupation of pavements and from public places, informal activities exercised confusedly, the proliferation of wild deposit of garbage, precarious housing environments, unfinished constructions, advertising posters and illegal panels, etc. This urban disorder is bound to the impoverishment, to the unemployment, to the insufficiency of economic infrastructures (markets, shopping malls), in the high cost of living, in the lack of preparation of grounds, etc. The consequences on the esthetic quality of the urban landscape and on the health of the populations are disturbing. The implementation of a mechanism of follow-up and coercive control of the undertaken actions and the effective implication of the populations can be the security of a healthy living environment.

\section{References}

Adomon, A. A. (2015). Assessment of the Decentralization Policy in Côte d'Ivoire, Case 
of the Municipalities of Alépé, Taabo and Yopougon (343 p.). Unique Thesis of Doctorate of Geography, Félix Houphouët Boigny University, Institute of Tropical Geography (IGT). https://hal-ens-lyon.archives-ouvertes.fr/tel-01337369

Adomon, A. A. (2016). Crisis of Management of Household Waste in Abidjan, The Answer of the Informal Private Precollectors in the Municipality of Yopougon (Côte d'Ivoire). Geoscience and Environment Protection, 4, 58-71. https://doi.org/10.4236/gep.2016.413004

Atta, K. (1994). Urban Planning: Legislation-Regulations-Practices Regarding Land Tax and Regarding Town Planning (26 p.). Abidjan: University of Cocody, SHS, IGT. [Not Published]

Attahi, K. (2001). Problem of the Urbanization and the Challenges of the Municipal Management in West and Central Africa (23 p.). Program of Urban Management, Abidjan: BNETD.

Bouquet, C., \& Kassi-Djodjo, I. (2014). "Leave" to Reconquer the Public Place in Abidjan. The Political Space, 22, 16 p. http://espacepolitique.revues.org/2963

Dembélé, O. (1997). The Model of Ivory Coast Town Planning in the Face of the Economic Crisis. Observation about the Metropolitan Housing Environment. In B. Contamin, \& H. Memel-Fotê (Eds.), The Ivory Coast Model in Question (pp. 483-513), Paris: Karthala-ORSTOM.

Diahou, Y. A. (1990). The State and the Municipalities in Côte d'Ivoire: A Game of Hide-and-Seek? African Politics, No. 40, 51-59.

Kamenan, B. M. (2007). The Risks of Natural Origin in Urban Zones: Case of the Floods in the Municipality of Cocody (162 p). Memory of Master's Degree, University of Abidjan Cocody, IGT. [Not Published]

Kouadio, O. R. (2012). Urban Extension and Natural Protection: The Difficult Experience of Abidjan. VertigO-The Electronic Magazine in Sciences of the Environment, 12, 24 p. http://vertigo.revues.org/12966

Kouamé, W. K. (2015). Conflicting Logics of Management of the Urban Public Places in Context Post-Conflict: The Example of Bouaké (Côte d'Ivoire). European Scientific Journal, 11, 229-243.

Ministry of the Environment, The Construction and The Town Planning (1993). Guide of the Construction and the Town Planning (55 p). Abidjan: Direction of the Construction and the Town Planning, Abidjan, Republic of Côte d'Ivoire.

Ministry of the Urban Healthiness, Republic of Côte d'Ivoire (2012). General Report of the Seminary on "Urban Disorder and Lack of Civic Virtue of the Populations: Which Responsibility of the Prefects" (11 p.). Yamoussoukro 1st, 2-3 November 2012, Member of Parliament.

RGPH-2014. Inventory Dress Rehearsal of the Population and the Housing Environment.

Soumahoro, M., \& Etongué, M. R. (2014). Tropical Urban Spaces: between Growth, Precariousness and Cultural Conflicts. Canadian Magazine of Tropical Geography, 1, $37-42$.

Vasseur, J.-F. (1997). Urban Disorders and Legal Regulations. The Paradox of "Entrances in Town". https://www.u-picardie.fr/curappseenagain/root/40/jeans 